\title{
The Production of $\beta-1,3$ Glucanase by a Thermophilic Species of Streptomyces
}

\author{
By G. LILLEY* AND A. T. BULL \\ Biological Laboratory, University of Kent, Canterbury $\mathrm{CT}_{2} 7 \mathrm{NJ}$ \\ (Received 23 November 1973; revised 13 February 1974)
}

SUMMAR Y

A $\beta$-I,3 glucanase-producing, thermophilic Streptomyces species was grown successfully in a chemically defined medium. Enzyme synthesis was semi-constitutive and subject to catabolite repression by metabolizable carbon substrates; it was inducible by gentiobiose, a molecule structurally unlike its substrate. The enzyme was truly extracellular. Maximum batch production of the glucanase was obtained by adding the inducer late in the fermentation.

\section{INTRODUCTION}

Remarkably little is known of the regulation of extracellular polysaccharases (Davies, I963; Bull, 1972). Thus, from studies of the regulation of cellulase synthesis, some authors (Mandels \& Reese, I960; Nisizawa, Suzuki \& Nisizawa, I97I) consider it to be an inducible enzyme, whilst others (Hulme \& Stranks, I97I; Fusee \& Leatherwood, I972) suggest that it is constitutive and that its synthesis may be controlled by catabolite repression. As a first step towards optimizing a process for $\beta$-I,3 glucanase production we attempted to define the regulatory control mechanisms operating on its synthesis so as to be able to adopt a rational approach to the design of a fermentation process.

Earlier workers suggested that extracellular $\beta$-I,3 glucanases were produced constitutively in fungi (Reese \& Mandels, 1959; Chesters \& Bull, 1963; Bull \& Chesters, 1966). Subsequently, Tanaka \& Phaff (1965) reported that $\beta$-r,3 glucanase was inducible in an isolate of Bacillus circulans. This paper deals with our analysis of the regulatory mechanisms controlling the synthesis of the extracellular polysaccharase $\beta$-I,3 glucanase $(\beta-\mathrm{I}, 3$ glucan 3-glucanhydrolase, EC. 3.2.I.6) produced by a thermophilic species of Streptomyces. A preliminary report of this investigation was made by Lilley \& Bull (I972).

\section{METHODS}

Organism. The Streptomyces species I 7 used in this study was isolated from pond mud of slightly acid $\mathrm{pH}$ which was heavily littered with decomposing vegetation. Organisms were isolated on a solid medium containing 'insoluble' laminaran (British Borax Co. Ltd, Liverpool) incubated at $50{ }^{\circ} \mathrm{C}$ in a humidified chamber. $\beta-\mathrm{I}, 3$ Glucanase producers were identified by haloes of clearing resulting from the hydrolysis of laminaran; the haloes were made distinct by precipitating the undegraded laminaran by incubating the Petri dish cultures overnight at $4{ }^{\circ} \mathrm{C}$.

Culture conditions. Stock cultures were maintained on agar slants containing, per litre: 'insoluble' laminaran, I0.0 g; bacteriological peptone (Oxoid), 2.5 g; anhydrous yeast

* Present address: Glaxo Research Ltd, Sefton Park, Stoke Poges, Buckinghamshire. 
extract (Difco), 2.5 g; $\mathrm{KH}_{2} \mathrm{PO}_{4}, 0.4 \mathrm{~g} ; \mathrm{MgSO}_{4} .7 \mathrm{H}_{2} \mathrm{O}, 0.05 \mathrm{~g} ; \mathrm{NaCl}, 0 . \mathrm{I}$; and trace amounts of $\mathrm{FeCl}_{3} \cdot 6 \mathrm{H}_{2} \mathrm{O}, \mathrm{MnCl}_{2} \cdot 4 \mathrm{H}_{2} \mathrm{O}$ and $\mathrm{CoCl}_{2} \cdot 6 \mathrm{H}_{2} \mathrm{O}$. Stocks were stored at $4{ }^{\circ} \mathrm{C}$ and subcultured every three to four months.

Batch cultivation was at $50{ }^{\circ} \mathrm{C}$ in a chemically defined liquid medium containing glycerol ( $5 \mathrm{~g} / \mathrm{l}$ ) as the principal carbon source and L-asparagine $(5 \mathrm{~g} / \mathrm{l})$ as the nitrogen source. The basal medium, to which glycerol and L-asparagine were added, contained per litre: $\mathrm{Na}_{2} \mathrm{HPO}_{4}$. I $2 \mathrm{H}_{2} \mathrm{O}, 9.5 \mathrm{~g} ; \mathrm{KH}_{2} \mathrm{PO}_{4}$, IO g; EDTA $\mathrm{Na}_{2} .2 \mathrm{H}_{2} \mathrm{O}, 0.6 \mathrm{~g} ; \mathrm{MgSO}_{4} .7 \mathrm{H}_{2} \mathrm{O}, 0.25 \mathrm{~g}$; $\mathrm{CaCl}_{2}, 0.05 \mathrm{~g} ; \mathrm{ZnSO}_{4} .7 \mathrm{H}_{2} \mathrm{O}, 0.02 \mathrm{~g} ; \mathrm{MnSO}_{4} .4 \mathrm{H}_{2} \mathrm{O}, 0.02 \mathrm{~g} ; \mathrm{CuSO}_{4} .5 \mathrm{H}_{2} \mathrm{O}$, $0.005 \mathrm{~g}$; $\mathrm{FeSO}_{4} .7 \mathrm{H}_{2} \mathrm{O}$, O.I g; $\mathrm{Na}_{2} \mathrm{SO}_{4}, 0.5 \mathrm{~g} ; \mathrm{Na}_{2} \mathrm{MoO}_{4} .2 \mathrm{H}_{2} \mathrm{O}$, 0.005 g; NaOH, o. I g; $\mathrm{CoCl}_{2} .6 \mathrm{H}_{2} \mathrm{O}$, $0.05 \mathrm{mg}$; and cyanocobalamin, $0.25 \mathrm{mg}$. The $\mathrm{pH}$ of the whole medium before autoclaving was $6 \cdot 4$ and was not readjusted after sterilization.

Inocula were grown at $50^{\circ} \mathrm{C}$ on a rotary shaker $(200 \mathrm{rev} . / \mathrm{min})$ in $250 \mathrm{ml}$ Erlenmeyer flasks fitted with stainless steel coil baffles and containing $30 \mathrm{ml}$ of medium. Initial experiments showed that a reproducible inoculum was best obtained from a two-stage seed culture system. Three discs of agar $(6 \mathrm{~mm}$ diam) covered with heavily sporing growth of the organism were cut from freshly grown plate cultures, inoculated into liquid glycerol medium and grown for $24 \mathrm{~h}$ on a shaker. Portions ( $\mathrm{I} \mathrm{ml}$ ) of this growth were inoculated into fresh medium and incubated similarly. After $12 \mathrm{~h}$, when the organism was growing exponentially and before the glycerol was totally consumed, the organisms were harvested, washed with sterile distilled water and used to inoculate a fermenter. The fermenter was a continuously stirred tank reactor type (L.H. Engineering Ltd, Stoke Poges, Buckinghamshire) constructed from a section of Pyrex glass pipe (QVF Ltd, Stoke-on-Trent) with stainless steel head and base plates through which probes were inserted for monitoring and controlling culture variables (Rowley \& Bull, 1973). The working volume was 21 , and to compensate for evaporation losses the fermenter was fitted with a reflux condenser. Temperature was controlled at $50{ }^{\circ} \mathrm{C}$ and the dissolved oxygen tension in the medium was not allowed to fall below $40 \%$ of saturation. Oxygen transfer rates were determined by the sulphite oxidation method of Cooper, Fernstrom \& Miller (I944).

Measurement of growth. A known volume of culture was pipetted into tared glass tubes, and centrifuged (4000 rev./min, Io min), washed with distilled water, dried at $110{ }^{\circ} \mathrm{C}$ for $\mathrm{I} 2 \mathrm{~h}$ and weighed.

Determination of glycerol concentration. Glycerol in the growth medium was assayed by the method of Neish (1952).

Glucanase assay. $\beta-1,3$ Glucanase activity in organism-free culture supernatants was measured by the release of reducing sugar from 'insoluble' laminaran. Total reducing sugar in the enzymic digests was determined, as glucose, by the Nelson-Somogyi method (Spiro, I966). Substrate $(0.5 \mathrm{ml}$ of a $0.5 \% \mathrm{w} / \mathrm{v}$, solution of 'insoluble' laminaran in $0.05 \mathrm{M}$-citrate phosphate buffer, $\mathrm{pH} 5.8$ ) was incubated with $0.5 \mathrm{ml}$ of an appropriately diluted enzyme solution for 10 min at $37^{\circ} \mathrm{C}$. The reaction was terminated by boiling the mixture in covered tubes for $20 \mathrm{~min}$. Substrate and enzyme blanks were run with each series of assays. One unit of $\beta$-I,3 glucanase activity was defined as that activity which released I $\mu \mathrm{M}$-reducing sugar, as glucose, per minute under the standard conditions of assay. Protein was determined by the method of Lowry, Rosebrough, Farr \& Randall (I95I).

Ultrasonication of organisms. A sample of culture $(40 \mathrm{ml})$ was centrifuged free of growth medium, washed twice with ice-cold citrate-phosphate buffer $(0.05 \mathrm{M}, \mathrm{pH} 5.8)$ then resuspended in the same solution to one-quarter of the original broth volume $(\beta-1,3$ glucanase activity was not detectable in the buffer after washing the organsisms). The concentrated suspension was treated with three 20 -s bursts of ultrasonics from an M.S.E. I50 W ultra- 
sonic disintegrator while cooled in an ice-salt bath. This treatment released $85 \%$ of the total protein in the organism.

Replacement culture. A replacement-culture system was developed in order to define the effects of culture variables on glucanase synthesis and to investigate its regulatory control. Organisms harvested from batch fermentations were washed once with replacement medium at $50{ }^{\circ} \mathrm{C}$ and then resuspended in fresh replacement medium, also held at $50^{\circ} \mathrm{C}$, to the original broth volume. A sample of this suspension was removed for dry weight determination and the remainder was distributed in $5 \mathrm{ml}$ amounts to prewarmed $250 \mathrm{ml}$ Erlenmeyer flasks containing $20 \mathrm{ml}$ replacement medium and incubated on a rotary shaker at $50{ }^{\circ} \mathrm{C}$. $\beta$ - I, 3 Glucanase was monitored during the incubation period.

The replacement medium was a phosphate-buffered mineral-salts solution ( $\mathrm{pH} 6 \cdot 4)$ having the same composition and molarity as the phosphate-buffer and mineral-salts components of the growth medium. The dry weight of organisms used in these experiments varied $13 \%$ from a mean but were constant for each experiment.

\section{RESULTS}

\section{Production of $\beta-\mathrm{I}, 3$ glucanase during batch cultivation}

Figure I shows the characteristic changes in fermentation parameters $(\mathrm{pH}$, glycerol utilization, biomass and $\beta-\mathrm{I}, 3$ glucanase production) as a function of fermentation time for the batch culture of Streptomyces sp. I7. Polysaccharase synthesis lagged behind growth, the maximum rate of synthesis corresponding to the late exponential growth phase when the glycerol content of the medium was much reduced. Plots of specific production rates (Terui, Okazaki \& Kinoshita, 1967) emphasized the growth-dissociated production of $\beta$-I,3 glucanase; a negative correlation between the specific rate of enzyme synthesis $(\epsilon)$ and the specific growth rate $(\mu)$ was observed (Fig. 2 ). These results were strongly suggestive of catabolite repression mediating the control of $\beta-\mathrm{I}, 3$ glucanase synthesis under these cultivation conditions, production occurring only as the growth rate declined and the glycerol concentration of the medium fell. Further investigations of the regulatory mechanisms controlling $\beta-1,3$ glucanase synthesis were made using the washed organism replacement system.

The data in Table I confirm that the Streptomyces $\beta$-I,3 glucanase was a strictly extracellular enzyme and that its release from the organism was not dependent on autolysis.

\section{Production of $\beta-\mathrm{I}, 3$ glucanase in replacement cultures}

Organisms harvested from the batch fermenter eight hours after inoculation had the greatest capacity for $\beta$-I, 3 glucanase synthesis (Fig. 3), therefore all subsequent replacement studies were made with $8 \mathrm{~h}$ grown organisms.

The replacement culture technique was used to test a large number of carbohydrates as possible inducers of $\beta$-I, 3 glucanase; representative data are given in Table 2. Paper chromatographic analysis of the substances under test did not reveal gross contamination by sugars or chemical modification during autoclaving. Only those substances containing the $\beta$-I, 6 glucosidic linkage were potent inducers. Furthermore, this data strongly suggested that gentiobiose, the $\beta-\mathrm{I}, 6$ glucose disaccharide, was the inducing moiety. Titration of the inducing activities of gentiobiose and Claviceps $\beta$-glucan (Fig. 4) showed that the optimal concentration of gentiobiose which produced the maximum effect was $0 . \mathrm{I} \mathrm{mg} / \mathrm{ml}$. At this concentration its effect was almost equal to that of Claviceps $\beta$-glucan at its optimal 


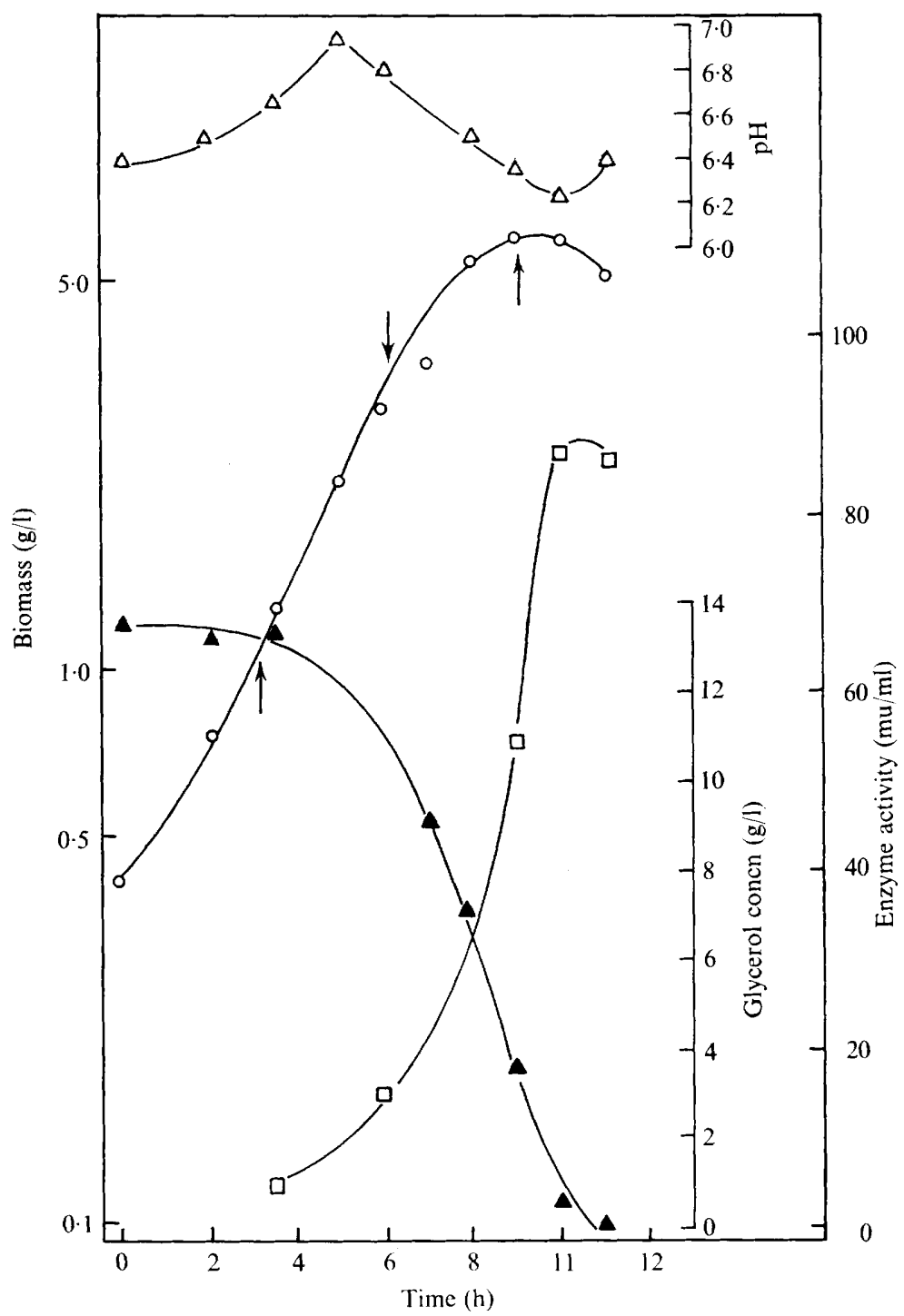

Fig. I. Batch cultivation of Streptomyces sp. 17. (O) Biomass production; '( $\square) \beta-1,3$ glucanase production; $(\Delta)$ glycerol concentration in the fermentation liquor; $(\triangle) \mathrm{pH}$ of the fermentation liquor. The arrows indicate the phases of growth referred to in Table $\mathrm{I} ; \mathrm{mu}=$ milliunits.

Table $\mathrm{I}$. The cellular location of $\beta$-I,3 glucanase

\begin{tabular}{lccc} 
Period of sampling & \multicolumn{3}{c}{$\beta-\mathrm{I}, 3$ Glucanase activity* (mu/ml whole culture broth) } \\
\cline { 2 - 3 } from batch culture & Supernatant fluid & $\begin{array}{c}\text { Supernatant fluid } \\
\text { from lysed organisms }\end{array}$ & $\begin{array}{c}\text { Pellet from } \\
\text { lysed organisms }\end{array}$ \\
Mid exponential & $\mathrm{I} 5.0(94)$ & $\mathrm{I} \cdot 0(6)$ & $\circ$ \\
Deceleration & $52.5(90)$ & $5 \cdot 0(8 \cdot 5)$ & $\mathrm{I} \cdot 0(\mathrm{I} \cdot 5)$ \\
Early stationary & $68.0(87)$ & $8 \cdot 0(\mathrm{I})$ & $2 \cdot 0(3)$
\end{tabular}

* Values in parentheses indicate percentages of extracellular, intracellular and bound enzyme, respectively, at each of the three phases of growth. 


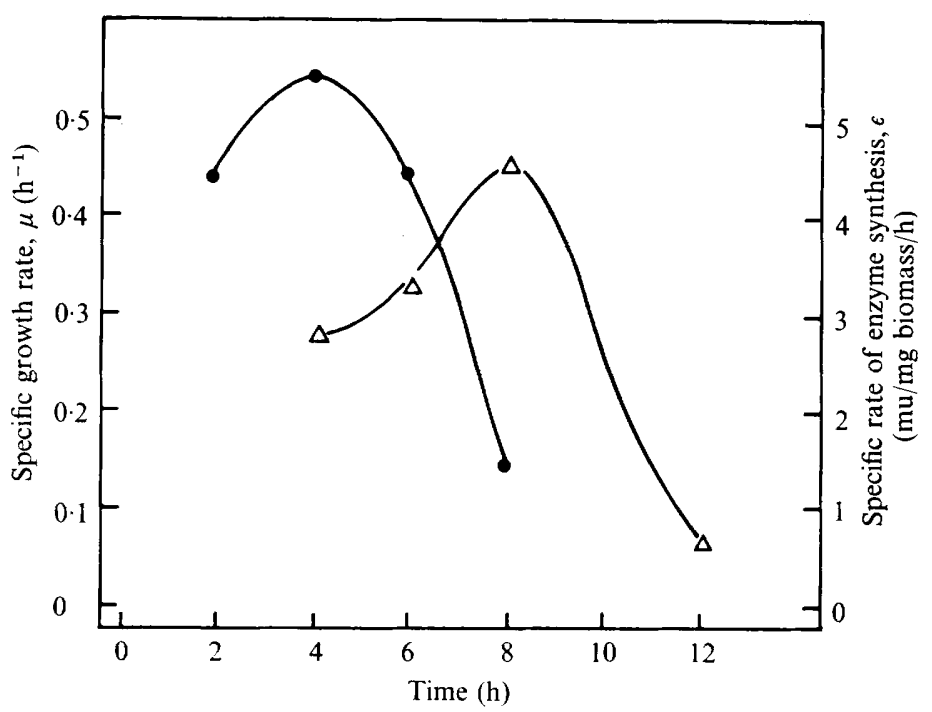

Fig. 2. The relationship between the specific rate of enzyme synthesis and the specific rate of growth for batch-grown organisms. (๑) Specific growth rate, $\mu ;(\triangle)$ specific rate of enzyme synthesis, $\epsilon$.

concentration, that is $\mathrm{I} \cdot 0 \mathrm{mg} / \mathrm{ml}$. The $\beta$ - I,3-linked disaccharide laminaribiose effected little or no stimulation of synthesis over the concentration range tested (Fig. 4).

Further experiments made with the replacement system determined that other optimal physical parameters for enzyme production were a $\mathrm{pH}$ of 5.8 to 6.4 , a temperature of $50{ }^{\circ} \mathrm{C}$ and an oxygen transfer rate of $90 \mathrm{mmol} / \mathrm{l} / \mathrm{h}$.

The catabolite repressibility of $\beta-\mathrm{I}, 3$ glucanase synthesis also was apparent from the replacement system studies. Both glycerol and glucose exerted a repressive effect under these nitrogen-free conditions (Fig. 5). A severe initial repression (transient repression) was followed by a permanent, less severe repression (catabolite repression). Glucose proved to have a more severe repressive effect than glycerol; however, the catabolite repressive effects of these substrates may be exaggerated by the nitrogen-limited conditions. Under such nongrowing conditions the entry of intermediates into catabolite pools may exceed the rate at which they are utilized for the synthesis of cellular material, and consequently an accumulation of catabolite repressors is probable. Inamine, Lago \& Demain (I969) observed that in a nitrogen-limited replacement medium all metabolizable carbon sources tested acted as catabolite repressors of $\alpha$-mannosidase synthesis. Synthesis of this enzyme was stimulated if an exogenous nitrogen source was added to the replacement medium, and subsequently greater concentrations of carbon sources were required to cause comparable repression. Similarly, gentiobiose-induced $\beta$-I,3 glucanase synthesis was stimulated by the addition of exogenous, non-inducing nitrogen sources to the replacement medium (Table 3 ).

L-Asparagine was also examined and the optimal concentration for its stimulatory effect was found to be 0.5 to $\mathrm{I} \cdot 0 \mathrm{mg} / \mathrm{ml}$.

Further studies with the growing batch system

Following the successful production of $\beta-\mathrm{I}, 3$ glucanase in replacement cultures, attempts were made to translate the data obtained to the growing batch system. The data accumulated from the replacement experiments indicated a semi-constitutive $\beta-1,3$ glucanase, inducible 


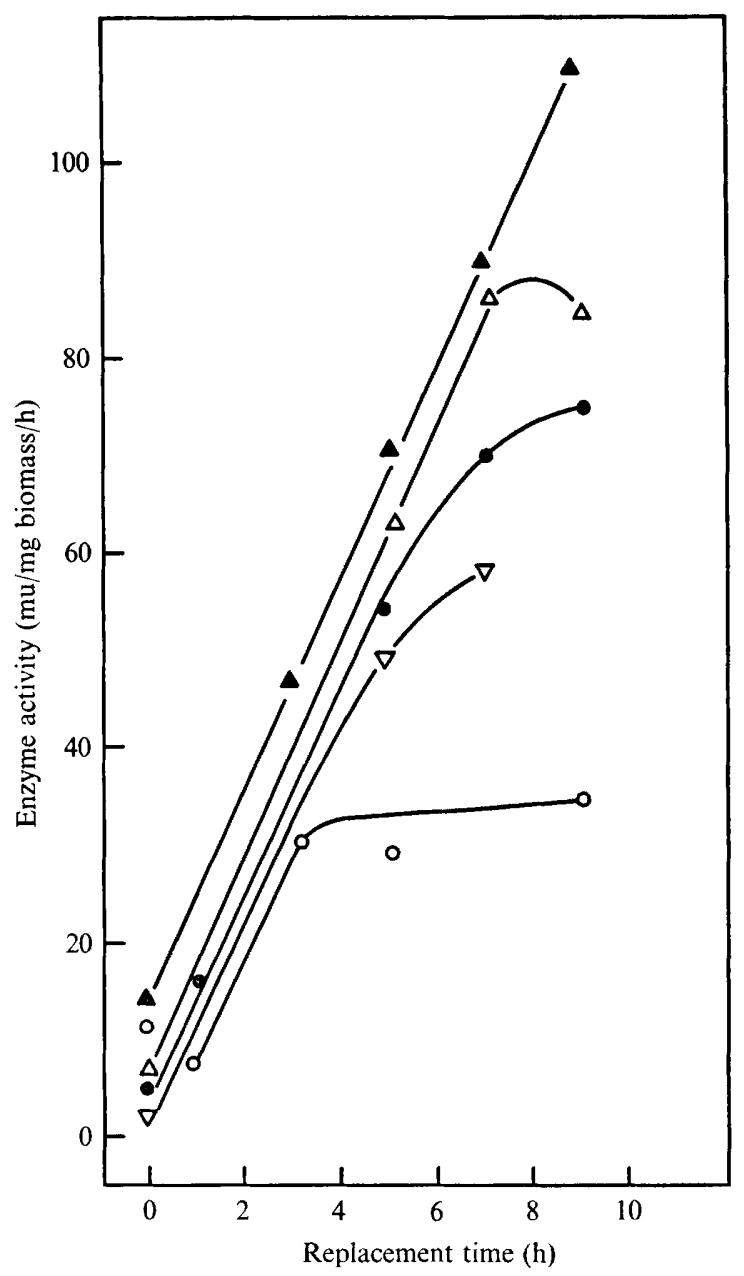

Fig. 3

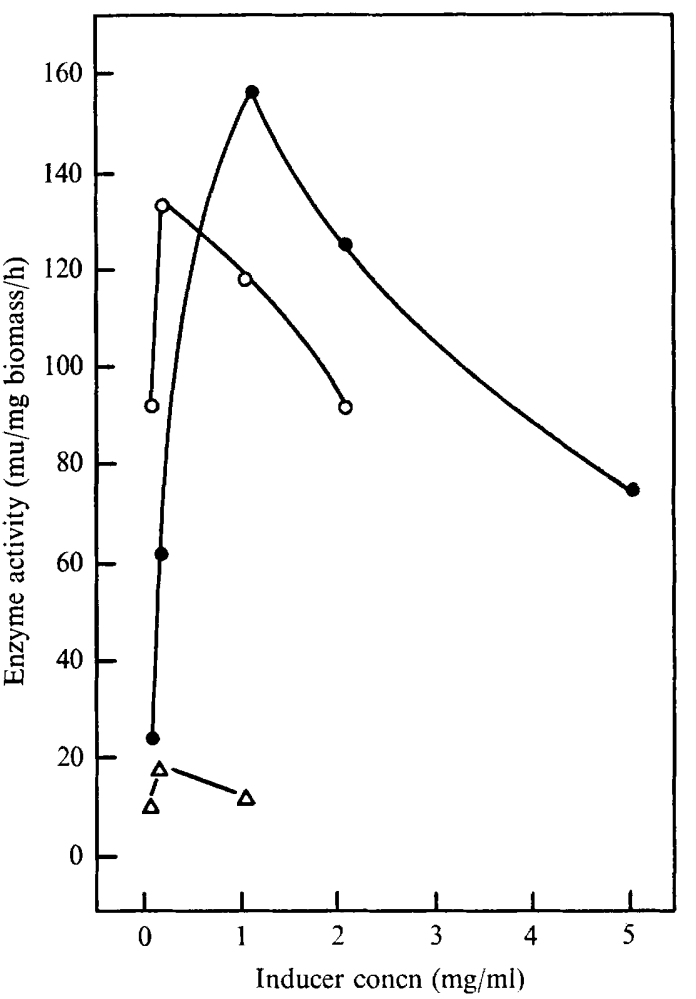

Fig. 4

Fig. 3. Effect of organism age on $\beta-\mathrm{r}, 3$ glucanase synthesis in the replacement system. (O) Four $\mathrm{h}$ grown organisms; $(\bullet) 6 \mathrm{~h}$ grown organisms; $(\boldsymbol{\Delta}) 8 \mathrm{~h}$ grown organisms; $(\Delta)$ Io h grown organisms; $(\nabla)$ i 2 h grown organisms.

Fig. 4. The effect of carbohydrate concentration on $\beta-1,3$ glucanase synthesis. The replacement medium was supplemented with Claviceps $\beta$-glucan $(\bullet)$, gentiobiose $(0)$ or laminaribiose $(\triangle)$, and $\beta-\mathrm{I}, 3$ glucanase activities were assayed after $3 \mathrm{~h}$ incubation.

by gentiobiose and sensitive to catabolite repression. Analysis of batch cultures further supported these conclusions; $\beta-\mathrm{I}, 3$ glucanase induction by gentiobiose was possible only if the inducer was added at a late stage of the fermentation (Fig. 6). On the other hand, Claviceps $\beta$-glucan could be added to the original growth medium because it was hydrolysed only after the major part of the glycerol had been utilized (Table 4); as a result, gentiobiose was reieased under non-catabolite repressing circumstances. 
Table 2. The effect of carbohydrates on $\beta$-I.3 glucanase synthesis

The replacement medium was supplemented with the compound under test ( $1 \mathrm{mg} / \mathrm{ml}$ ) and washed $8 \mathrm{~h}$ batch-grown organisms were resuspended in the medium. $\beta-1,3$ Glucanase was monitored throughout a subsequent incubation period of $13 \mathrm{~h}$.

\begin{tabular}{|c|c|c|c|c|}
\hline \multirow[b]{2}{*}{ Carbohydrate* } & \multicolumn{3}{|c|}{ Linkage type $\dagger$} & \multirow{2}{*}{$\begin{array}{c}\text { Induction rate } \\
\text { (mu enzyme } / \mathrm{mg} \\
\text { dry weight } / \mathrm{h} \text { ) }\end{array}$} \\
\hline & $\beta-\mathbf{I}, 3$ & $\beta-\mathrm{I}, 4$ & $\beta=\mathrm{I}, 6$ & \\
\hline Claviceps $\beta$-glucan & 70 & . & 30 & 46 \\
\hline Gentiobiose & . & . & 100 & 29 \\
\hline Aspergillus nidulans hyphal wall & + & . & + & 28 \\
\hline Pustulan & . & . & 100 & 23 \\
\hline$\beta$-I, 6 Substituted laminaran & 70 & . & 30 & 23 \\
\hline Neurospora crassa hyphal wall & + & . & + & 18 \\
\hline Lichenin & 35 & 65 & . & 8 \\
\hline Glucose & . & . & . & 8 \\
\hline Laminaritriose & 100 & . & . & 7 \\
\hline Laminaran & 95 & . & 5 & 7 \\
\hline Bukuryo & + & . & + & 6 \\
\hline Glycerol & . & . & . & 6 \\
\hline Laminaribiose & 100 & . & . & 5 \\
\hline Curdlan & 100 & . & . & 5 \\
\hline Starch & . & . & . & 4 \\
\hline Succinoglucan & + & . & + & 4 \\
\hline Pachyman & 100 & . & . & 4 \\
\hline No additions & . & - & . & 4 \\
\hline Cellobiose & . & 100 & . & 3 \\
\hline Barley $\beta$-glucan & 50 & 50 & . & 3 \\
\hline
\end{tabular}

* Sources of materials: bukuryo, curdlan and succinoglucan, $\mathrm{Ca}^{2+}$ form (Professor T. Harada, Osaka University, Japan); $\beta$-I, 6 substituted laminaran ex Ustilago zeae QM990 (Dr D. E. Eveleigh, Rutgers University, New Jersey, U.S.A.); pachyman (Professor B. A. Stone, La Trobe University, Melbourne, Australia); pustulan (Dr E. T. Reese, Natick, Massachusetts, U.S.A.); barley $\beta$-glucan (Dr W. O. S. Meredith, Department of Agriculture, Winnipeg, Canada); Claviceps $\beta$-glucan, ex C. fusiformis (Dr K. W. Buck, Imperial College, London); purified laminaran (Institute of Seaweed Research, Musselburgh, Scotland). The fungal walls were prepared by one of us (Bull, 1970). All other carbohydrates were obtained from commercial sources.

$\dagger$ Approximate percentage of linkage type present in the carbohydrate.

Table 3. The effect of nitrogenous compounds on gentiobiose-induced $\beta$-I,3 glucanase synthesis

Replacement medium was supplemented with $0 . \mathrm{I} \mathrm{mg}$ gentiobiose $/ \mathrm{ml}$ and I $\mathrm{mg}$ of the nitrogen source under test $/ \mathrm{ml}$. Enzyme activity was assayed after $3 \mathrm{~h}$ incubation.

Nitrogen source

Casein hydrolysate

Corn steep liquor

Cotton seed nutrients

L-Asparagine

Ammonium sulphate

Urea

No nitrogen addition

Sodium nitrate

Sodium nitrite
Glucanase activity (mu/mg dry weight)

$\overbrace{\text { Plus gentiobiose }}^{\frac{2}{\text { Glucanase activity }}(\mathrm{mu} / \mathrm{mg} \text { dry weight })}$

* Not determined. 


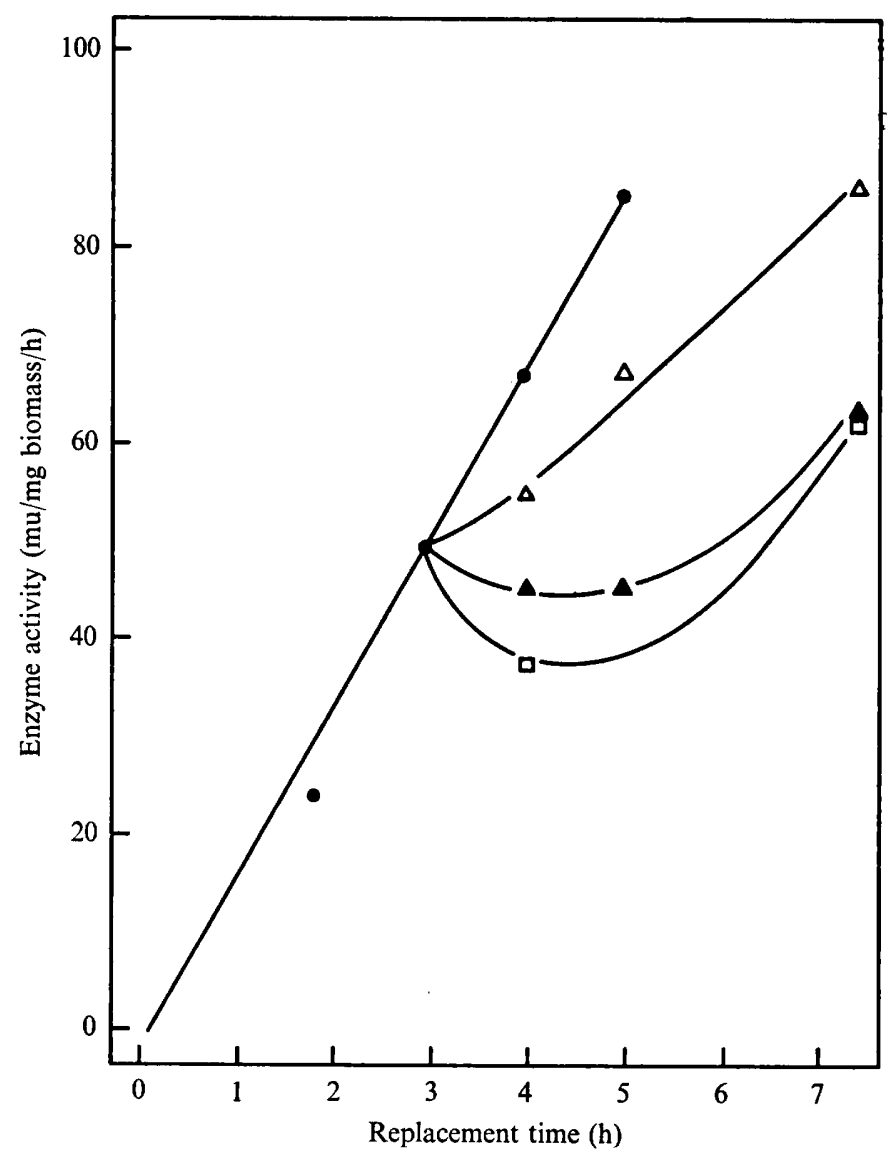

Fig. 5. Effect of glucose and glycerol on $\beta-1,3$ glucanase synthesis: catabolite repression. Replacement medium was supplemented with $0.1 \mathrm{mg}$ gentiobiose $/ \mathrm{ml}$ and exogenous repressors were added $3 \mathrm{~h}$ after the start of enzyme synthesis. (๑) Control; ( $\square$ ) glucose, $1 \mathrm{mg} / \mathrm{ml} ;(\triangle, \Delta)$ glycerol, 5 and $15 \mathrm{mg} / \mathrm{ml}$ respectively.

Table 4. Effect of gentiobiose and Claviceps $\beta$-glucan on $\beta$-I,3 glucanase synthesis in growing batch cultures

The chemically defined growth medium was supplemented with Claviceps $\beta$-glucan ( $1 \circ \mathrm{g} / \mathrm{l})$ or gentiobiose ( $(\cdot \mathrm{I} g / \mathrm{l}) . \beta-\mathrm{I}, 3$ Glucanase, glycerol and biomass levels were monitored during the batch growth of Streptomyces $\mathbf{I} 7$ in the supplemented and unsupplemented (control) media.

\begin{tabular}{|c|c|c|c|c|c|c|}
\hline \multirow{2}{*}{$\begin{array}{l}\text { Age of batch } \\
\text { culture sample }\end{array}$} & \multicolumn{3}{|c|}{$\begin{array}{l}\beta-\mathbf{I}, 3 \text { Glucanase activity } \\
(\mathrm{mu} / \mathrm{mg} \text { dry weight })\end{array}$} & \multicolumn{3}{|c|}{$\begin{array}{l}\text { Glycerol concentration } \\
\text { in the fermentation broth } \\
(\mathrm{g} / \mathrm{l})\end{array}$} \\
\hline & Control & Gentibiose & Glucan & Control & Gentibiose & Glucan \\
\hline Mid exponential & $9 \cdot 5$ & $10 \cdot 2$ & $9 \cdot 3$ & $13 \cdot 2$ & I $2 \cdot 8$ & 13.9 \\
\hline Deceleration & II $\cdot 4$ & II $\cdot 7$ & $13 \cdot 2$ & $9 \cdot I$ & $9 \cdot 6$ & $8 \cdot 9$ \\
\hline Early stationary & $\mathrm{II} \cdot 9$ & I $2 \cdot \mathrm{I}$ & $59 \cdot 0$ & 0.7 & $I \cdot 2$ & 0.9 \\
\hline
\end{tabular}




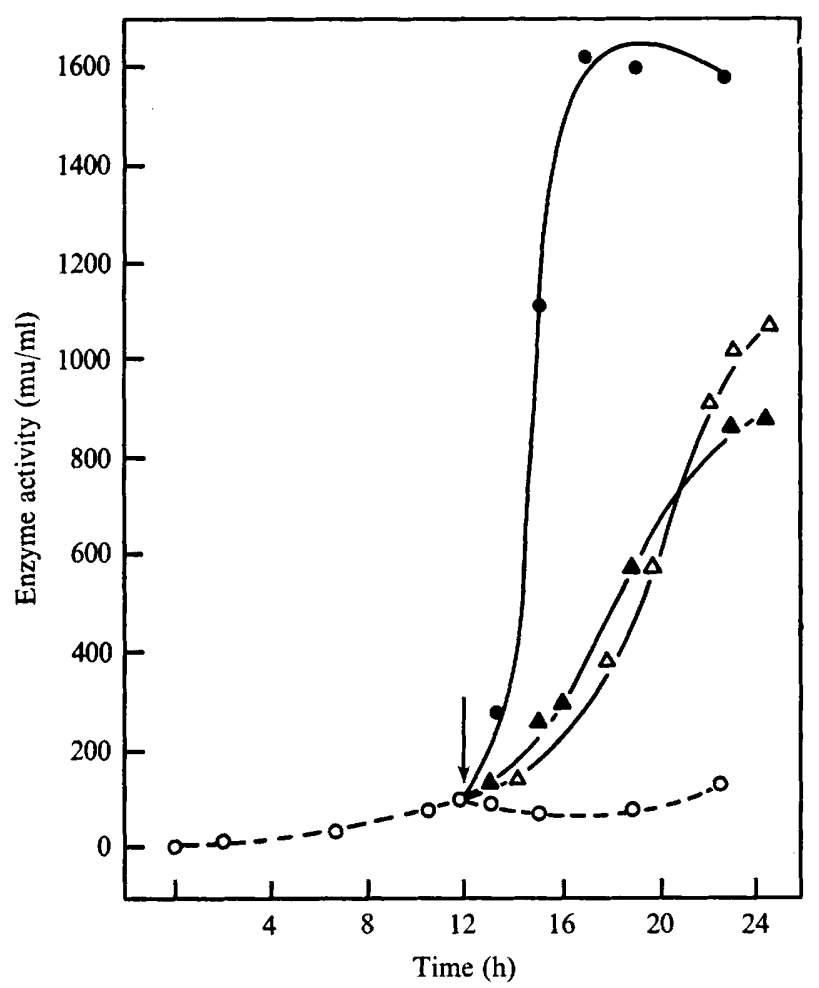

Fig. 6. The effect of gentiobiose and Claviceps $\beta$-glucan on $\beta$-I,3 glucanase in growing batch cultures. Additions were made to separate fermentations at the time indicated by the arrow and $\beta$-I,3 glucanase synthesis monitored. No additions were made to the control culture $(0) .(\Delta, \Delta)$ Gentiobiose, 0.1 and $0.2 \mathrm{mg} / \mathrm{ml}$ respectively; (O) Claviceps $\beta$-glucan, I. $0 \mathrm{mg} / \mathrm{ml}$.

\section{DISCUSSION}

The results of the batch and organism replacement cultures suggest that the $\beta$-I,3 glucanase of Streptomyces sp. 17 is an extracellular enzyme sensu stricto, is semi-constitutive and is subject to catabolite repression. Similar conclusions have been made for a number of other extracellular polysaccharases. For example, cellulase production by Myrothecium verrucaria grown in glucose- or glycerol-limited batch cultures (Hulme \& Stranks, I97I), glucamylase production by Aspergillus niger (Okazaki \& Terui, I967) and $\alpha$-amylase production by Bacillus subtilis (Kinoshita, Okada \& Terui, 1967) are reported to be under similar control. Ortiz, Berkeley \& Brewer (1973) have shown that the synthesis of $\beta-N$ acetylglucosaminidase by $B$. subtilis $\mathrm{B}$ is regulated by a substrate induction-catabolite repression balance.

The extent of $\beta-\mathrm{I}, 3$ glucanase synthesis in the replacement medium was dependent upon organism age. However, the rate of glucanase synthesis was constant under these conditions, suggesting that some factor other than the persistence of endogenous repressors was responsible for the age dependency. Somewhat comparable age-dependent induction kinetics have been observed for intracellular enzymes (Pavlasova, Stejskalova \& Necinova, 1967). The effectiveness of Aspergillus nidulans and Neurospora crassa walls as glucanase inducers is in agreement with Tanaka's earlier observation on the stimulation of $\beta-1,3$ glucanase synthesis in Bacillus circulans by walls of baker's yeast (Tanaka \& Phaff, I965). 
We consider that the fungal walls and mixed linkage $\beta-\mathrm{I}, 3 ; \beta-\mathrm{I}, 6$ glucans such as Claviceps $\beta$-glucan- and $\beta$-I,6-substituted laminaran manifest their inducing properties via the hydrolytic release of gentiobiose when they are attacked by $\beta-\mathrm{I}, 3$ glucanase. The observations of Nelson, Johnson, Jantzen \& Kirkwood (1969) on the action pattern and specificity of an exohydrolytic $\beta$-I,3 glucanase from Basidiomycete sp. QM806 gives credence to this suggestion. These workers found that when $\beta$-I,3; $\beta$-I, 6 mixed-linkage glucans were used as substrates for the exohydrolytic enzyme, the $\beta-1,6$ linkages were by-passed and gentiobiose was released.

Our present data indicate that conditions optimal for basal $\beta-1,3$ glucanase production are those which do not favour balanced vegetative growth, a situation similar to that reported by some workers as being optimal for cellulase formation (Hulme \& Stranks, I97I). Moreover, $\beta$-I,3 glucanase synthesis is induced by a molecule structurally dissimilar from its substrate and in this respect induction of the Streptomyces enzyme is analogous to the effect of sophorose (2-O- $\beta$-D-glucopyranosyl-D-glucose) on cellulase synthesis (Mandels, Parrish \& Reese, 1962; Yamane et al. 1970). The action patterns of $\beta-1,3$ glucanase produced constitutively in the glycerol medium and induced by gentiobiose, with laminaran as substrate, were identical and consistent with endohydrolytic activity (see Bull \& Chesters, I966). New glucanase activities were not induced by gentiobiose. It should be emphasized that gentiobiose did not induce a $\beta-1,6$ glucanase; the constitutive and induced $\beta-1,3$ glucanase preparations had similar, very low activities against the appropriate test substrate, pustulan.

Further analyses of the regulatory mechanisms have been made in chemostat cultures and our results suggest that gentiobiose does not act as an inducer in the generally accepted sense. The results of these experiments will be reported in a subsequent publication.

We acknowledge the Lord Rank Research Centre's sponsorship of this project and thank those who gave us samples of polysaccharides.

\section{REFERENCES}

Bull, A. T. (1970). Chemical composition of wild-type and mutant Aspergillus nidulans cell walls. The nature of polysaccharide and melanin constituents. Journal of General Microbiology 63, 75-93.

Bull, A. T. (1972). Environmental factors influencing the synthesis and excretion of exocellular macromolecules. Journal of Applied Chemistry and Biotechnology 22, 26 I-292.

Bull, A. T. \& Chesters, C. G. C. (1966). The biochemistry of laminarin and the nature of laminarinase. Advances in Enzymology 28, 325-364.

Chesters, C. G. C. \& Bull, A. T. (1963). The enzymic degradation of laminarin. I. The distribution of laminarinase among microorganisms. Biochemical Journal 86, 28-31.

Cooper, C. M., Fernstrom, G. A. \& Miller, S. A. (I944). Performance of agitated gas-liquid contactors. Industrial and Engineering Chemistry 36, 504-509.

DAvies, R. (1963). Microbial extracellular enzymes, their uses and some factors affecting their formation. In Biochemistry of Industrial Microorganisms, pp. 68-150. Edited by C. Rainbow and A. H. Rose. New York: Academic Press.

Fusee, M. C. \& LeATHERWOOD, J. M. (1972). Regulation of cellulase from Ruminococcus. Canadian Journal of Microbiology r8, 347-353.

Hulme, M. A. \& Stranks, D. W. (197I). Regulation of cellulase production by Myrothecium verrucaria grown on non-cellulosic substrates. Journal of General Microbiology 69, 145-I55.

InAmine, E., Lago, B. D. \& Demain, A. L. (1969). Regulation of $\alpha$-mannosidase, an enzyme of streptomycin biosynthesis. In Fermentation Advances, pp. 199-22I. Edited by D. Perlman. New York: Academic Press.

Kinoshita, S., Okada, H. \& Terui, G. (1967). Kinetic studies on enzyme production of microbes. II. Process kinetics of $\alpha$-amylase production by Bacillus subtilis. Journal of Fermentation Technology 45, 504-510. 
Lilley, G. \& Bull, A. T. (I972). $\beta$-I,3 Glucanase production by a thermophilic Streptomycete. Journal of General Microbiology $\mathbf{7 1}$, ix.

Lowry, D. H., Rosebrough, N. J., Farr, A. L. \& Randall, R. J. (I951). Protein measurement with the Folin phenol reagent. Journal of Biological Chemistry 193, 265-275.

Mandels, M., Parrish, F. W. \& Reese, E. T. (1962). Sophorose as an inducer of cellulase in Trichoderma viride. Jommal of Bacteriology $\mathbf{8}, 400-408$.

Mandels, M. \& Reese, E. T. (1960). Induction of cellulase in fungi in cellobiose. Journal of Bacteriology 79 , $816-826$.

NeISH, A. C. (1952). Colorimetric determination of formaldehyde formed on periodate oxidation (glycerol). In Analytical Methods for Bacterial Fermentations, pp. 36-37. National Research Council of Canada, Report No. 46-8-3.

Nelson, T. E.. Johnson, J., Jantzen, E. \& Kirkwood, S. (I969). Action pattern and specificity of an exo- $\beta$ ( I-3)-D-glucanase from Basidiomycete species QM 806. Journal of Biological Chemistry 244, 5972-5980.

Nisizawa, T., SuzUKi, H. \& Nisizawa, K. (I97I). De novo synthesis of cellulase induced by sophorose in Trichoderma viride cells. Journal of Biochemistry 7o, 387-393.

Okazaki, M. \& Terui, G. (1967). Kinetic studies on enzyme production by microbes. IJI. Process kinetics of glucamylase production by Aspergillus niger. Journal of Fermentation Technology 45, I $147-1$ I 55.

Ortiz, J. M., Berkeley, R. C. W. \& Brewer, S. J. (1973). Production of exo- $\beta$ - $N$-acetylglucosaminidase by Bacillus subtilis B. Journal of General Microbiology 77, 331-337.

Pavlasova, E., Stejskalova, E. \& Necinova, S. (1967). Induction of amylomaltase and $\beta$-galactosidase in different growth phases of Escherichia coli. Currents in Modern Biology 1, 196-199.

ReEse, E. T. \& MANDels, M. (1959). $\beta$-D-1,3 Glucanase in fungi. Canadian Journal of Microbiology 5, 173I 85 .

Rowley, B. I. \& Bull, A. T. (1973). A chemostat for filamentous moulds. Laboratory Practice 22, $286-289$.

Spiro, R. G. (1966). Analysis of sugars found in glycoproteins. In Methods in Enzymology, vol. 8, pp. 3-26. Edited by E. F. Neufeld and V. Ginsburg. New York: Academic Press.

Tanaka, H. \& Phaff, H. J. (1965). Enzymatic hydrolysis of yeast cell walls. Journal of Bacteriology $8 \mathbf{9}$, $1570-1580$.

Terui, G., Okazaki, M. \& Kinoshita, S. (1967). Kinetic studies on enzyme production by microbes. I. Kinetic models. Journal of Fermentation Technology 45, 497-503.

Yamane, K., Suzuki, H., Hirotani, M., Ozawa, H. \& Nisizawa, K. (I970). Effect of nature and supply of carbon sources on cellulase formation in Pseudomonas fluorescens var. cellulosa. Journal of Biochemistry $67,9-18$. 